\title{
Challenges and Strategies in Teaching Speaking Skills to the Yemeni EFL Learners at Aden University: A Case Study
}

\author{
Abdulbari Mahboob Ahmed Al-Hassaani \\ Department of English, College of Education, University of Aden, Aden, Yemen \\ $\&$ \\ Department of English, College of Arts, University of Bisha, Bisha, Saudi Arabia \\ Correspondent Author: barihasani9@gmail.com
}

Abdulkarim Fadhl Mahmood Qaid

Department of English, College of Education, Saber, University of Aden Aden, Yemen

Recived: $11 / 22 / 2020$

Accepted: $1 / 26 / 2021$

Published: 3/24/2021

\begin{abstract}
This study focused on Yemeni EFL learners of second-year level, Department of English, College of Education/Saber, Aden University. Yemeni learners started to study English in class seven at the age of about 14, and this is a problem for Yemeni EFL learners. Besides, Yemeni EFL learners' problems were inadequate syllabus and inappropriate teaching materials of English-speaking skills course. The researchers identified a problem existing in the classroom. The learners in this college faced difficulties in their study of English-speaking skills at Aden University. This was because of their limited background in English. They felt anxiety and fear of making mistakes. The study's main objective was to examine the difficulties faced by the Yemeni EFL learners in English-speaking skills course at Aden University. The study contributed to finding remedies to the Yemeni EFL learners' problems in English -speaking skills. It would also help syllabus designers, teaching materials writers, learners, and teachers at Aden University. We conclude that the Yemeni EFL learners need enough time to practice English-speaking skills at Aden University. The current syllabus and teaching materials for teaching English-speaking skills need to be changed and developed to match the learners' needs in the labor market.
\end{abstract}

Keywords: Aden University, challenges, English language, speaking skills, strategies, Yemeni EFL learners

Cite as: Al-Hassaani, A. M. A., \& Qaid, A. F. M. (2021). Challenges and Strategies in Teaching Speaking Skills to the Yemeni EFL Learners at Aden University: A Case Study. Arab World English Journal, 12 (1) 498 -514. DOI: https://dx.doi.org/10.24093/awej/vol12no1.32 


\section{Introduction}

This study was concerned with a case study of challenges and strategies in teaching Englishspeaking skills course to the second-year Yemeni EFL learners, English Department, College of Education, Saber, Aden University. Despite the long period of learning English as a foreign language, the Yemeni EFL learners still face difficulties in English-speaking skills when they speak at university. They lack motivation and enough practice of English-speaking skills. They were exposed to the English language late at level seven of intermediate school. Inhibition refers to the students being afraid of making mistakes. Fearing criticism and being shy also inhibit the learners from speak the second or foreign language. This factor affects the speaking fluency of the Yemeni EFL learners. When the learners are afraid of mistakes, they are probably more hesitant, Al-Ghazali (2019). Any speaking performance plan to practice phonological or grammatical features of language can be self-initiated or pair-work (Brown, 2007). Therefore, speaking a foreign language was not as easy as our mother tongue language because of its different complex rules in applying and constructing English sentences.

\section{The rationale of the study}

This study would help to understand the problems and factors that hinder the learning process of English-speaking skills at Aden University. It would also help to improve the situation in teaching the "English Speaking Skills." Besides, it might also help raise awareness of teachers and learners in mastering English speaking skills at Aden University. Concerning the study's significance, the current study will identify the problems encountered by the Yemeni EFL learners, and it will help syllabus designers, teaching materials writers, learners, teachers, and other concerned people. This study will befit both the teachers and the learners.

\section{The research questions}

The research questions were designed keeping in mind the objectives of the study. The current study attempted to find an answer to the following research questions:

1.What are the problem areas that encounter the Yemeni EFL learners in English-speaking skills?

2.How adequate is the syllabus for the course English-speaking skills at Aden University?

3. To what extent are the teaching materials appropriate for the Yemeni EFL learners in learning

English-speaking skills at Aden University?

\section{The Objectives of the Study}

1. To examine the challenges encountered by Yemeni EFL learners in English speaking skills at Aden University.

2. To investigate the appropriateness of teaching materials for English-speaking skills, tasks, activities, and strategies used in teaching English speaking skills.

3. To investigate the syllabus' adequacy for English speaking skills in the learning process.

\section{Review of Literature}

Yemeni EFL learners face challenges in English-speaking skills at Aden University. No one can deny that English language speaking is essential for all EFL learners because it is the way to communicate orally with others. Lack of environment, interest, and motivation are the most critical factors that affect learners' speaking skills, Ali (2019). 
English speaking skill needs a high-level experience and a good background. Dewi (2015) pointed out that English was used in every corner of the world as a medium to interact among people from different cultural, ethnic, and social backgrounds. Al Hosni (2014) clarified that anxiety and unwillingness in speaking skills lessons are the two main obstacles to learning English. University instructors who teach English should focus on essential features such as fluency and accuracy in their teaching. They should be fluent and accurate in learning English language speaking skills, focusing on grammatical structures, vocabulary, and pronunciation. Strategies of speaking skills were considered to be strategies of communication. One of the purposes of English language teaching in the Yemeni universities is to improve the learners' comprehensive ability, especially the oral expression, and to encourage them to have adequate opportunities to use the foreign language fluently, Al-Tamimi (2014). Yemeni learners were less exposed to the English language because it was introduced to them later. English speaking skill was considered one of the most challenging aspects of the language for EFL learners in the Arab world. Most of the Yemeni EFL learners found difficulty to express themselves correctly in spoken English. Gathumbi and Masembe (2005) identified that learner-centered classroom activities, including story-telling, speeches, debates, and group discussions, could alleviate the problem of poor oral skills. The student-centered approach allows the learners to work together, feel free of fear, correct each other, and practice English-speaking skills in the classroom rather than teacher-centered. Of course, they need the teacher's corrective feedback during the speaking lessons.

As university researchers, we realized that motivation and encouragement are the most critical factors to improve the Yemeni EFL learners. If English learners are well-motivated to practice different real-life situations, their oral communication in English-speaking skills would be improved. Motivation and encouragement are two faces for one coin. Al-Hosni (2014) observed that some learners lack the motivation to speak English because they do not see the need to learn or speak English. Therefore, teachers of English language should explain to their learners the great significance of learning English-speaking skills.

Speaking is an essential part of communication, especially in learning a language for social interaction and other communicative purposes on different occasions. Richard (2006) said the ever-going need for good communication skills in English has emerged in high demand around the world. Speaking is one of the essential skills in English, because it occupies a superior status. Therefore, English teachers must give priority to English-speaking skills in the classroom. This indicated that a real communicative approach should be adopted when teaching English classes. Besides, English-speaking skills are of vital importance for the learners in and outside the classroom. In communicative approach, language is essentially or an instrument of communication. Brown (2007) indicated that communicative language teaching is an approach to language teaching methodology that emphasizes authenticity, interaction, student-centered learning, task-based activities, and real-world communication. Effective communication of speaking skills creates many benefits for communicating in both languages, the targeted language and mother tongue language. The foreign language learner has had the experience of another mother tongue language. He tries to learn the foreign language how he obtained the first language but finds that the environment and the surroundings in which he received his mother tongue (first language) are not available for him now. He now tries to learn consciously, AlAhdal (2014). 
The communicative syllabus was classified into three categories:1) A situational or contextual syllabus. 2) A topical or thematic syllabus. 3) A notional (functional) syllabus (Shaw, 1982). A finished syllabus is an overall plan for the learning process. The ultimate aim of language teaching is to improve the learners' communicative ability to use the language at ease and with confidence. Therefore, the present-day English syllabus should focus on communicative English to attain the desired teaching objectives of speaking skills.

\section{Communicative Language Teaching Materials}

Teaching materials in a communicative instructional system have the primary function of promoting communicative language use; this teaching strategy will help teachers and will have an excellent contribution to the improvement of the Yemeni learners' level in English speaking skills. According to Richards and Rodgers (1986), there are three kinds of materials used; 1) Text-based materials. 2) Task-based. 3) Realia. Teachers at Aden University should provide a variety of authentic communicative materials in teaching English-speaking skills to improve their learners' level at Aden University.

\section{Methods}

This research used a quantitative questionnaire research method for data collection. According to Sarantakos (1998), questionnaires, as ways of data collection, have many advantages, and some of these include the following:

- They produce a quick result.

- They offer greater assurance of anonymity.

- The use of questionnaires promises comprehensive coverage since researchers can approach respondents more quickly than other methods.

\section{Population}

The respondents who participated in this study were from the English Department, secondyear level, College of Education / Saber; Aden University. The total number of respondents was 60 students, the female respondents were 40 girls, and the male respondents were 20 boys.

\section{Research Design}

The researchers designed the research tool a questionnaire for the learners. The researchers gave it to ELT experts in English Departments at three different universities before distributing and administering it, to ensure the validity and standard of the research tool. The questionnaire distributed and administered in classrooms during the second semester, in 2019, College of Education, Saber, Aden University.

\section{Discussions of the Study}

The research tool was a quantitative scientific method for collecting data and information, and it was classified into four parts. The first part was about the general background knowledge of the learners. The second part was about learners' main difficulties when they speak English with others; the third part was about the reasons behind learners' English-speaking skill problems and students' motivation to learn English. The fourth part was about the learners' exposure to the English language and speaking; and the learners' opinion about the appropriateness of the syllabus and teaching materials for English speaking skill course at Aden University. 
Arab World English Journal (AWEJ) Volume 12. Number 1. March 2021

Challenges and Strategies in Teaching Speaking Skills to the Yemeni

Al-Hassaani \& Qaid

Table 1. Sex of the Learners

\begin{tabular}{lcl}
\hline & \multicolumn{2}{c}{ Responses } \\
\hline Sex & Frequency & Percentage \\
Female & 40 & 66,7 \\
Male & 20 & 33.3 \\
Total & 60 & 100 \\
\hline
\end{tabular}

The above table showed the sex of the respondents who participated in this study, of whom forty respondents, $66.7 \%$, were female, and twenty respondents, $33.3 \%$, were male.

Table 2. Educational Background of the Learners at High School

\begin{tabular}{lll}
\hline & & Responses \\
\hline Status & Frequency & Percentage \\
\hline Urban & 24 & 40 \\
Rural area & 35 & 58.3 \\
No response & 1 & 1.7 \\
Total & 60 & 100 \\
& & \\
\hline
\end{tabular}

The researchers asked the learners about their educational background at the high school level. Twenty-four of the learners, $40 \%$, had their schooling in urban areas, while thirty-five of the learners, $58.3 \%$, in schools of rural areas. Only one learner, $1.7 \%$, not replied. It indicated that the rural regions are keeping pace with urban areas in providing education to learners.

Table 3. Schools of the Learners at High School

\begin{tabular}{ccc}
\hline & \multicolumn{2}{c}{ Responses } \\
\hline Status & Frequency & Percentage \\
\hline Government school & 45 & $75 \%$ \\
Private school & 15 & $25 \%$ \\
Total & 60 & 100 \\
\hline
\end{tabular}

We asked the learners at which school they went to at high school. Forty-five of the learners, $75 \%$, answered that they went to government schools. In comparison, fifteen of the learners, $25 \%$, answered they went to private schools when they were at the high school. It implied that most of the Yemen learners had no money to afford the education costs in private schools because of their family financial problems. 
Arab World English Journal (AWEJ) Volume 12. Number 1. March 2021

Table 4. Learners Began Studying English in Yemini Government Schools

\begin{tabular}{lcc}
\hline \multicolumn{1}{c}{ Status } & \multicolumn{2}{c}{ Responses } \\
\hline Class & Frequency & Percentage \\
\hline One & 0 & $0 \%$ \\
Two & 0 & $0 \%$ \\
Three & 0 & $0 \%$ \\
Four & 0 & $0 \%$ \\
Five & 0 & $0 \%$ \\
Six & 0 & $0 \%$ \\
Seven & 60 & $100 \%$ \\
Total & 60 & $100 \%$ \\
\hline
\end{tabular}

The researchers asked the learners which class they began to study English. Sixty of the learners, $100 \%$, answered they began to study English in class seven, and no one of them opted for other classes. This indicated that all the learners in Yemini government schools learned English at a late stage, which would not enable them to handle English courses in the College of Education, Department of English, Aden University.

The second part of the questionnaire consisted of seven items. They were about the challenges that the learners faced. If they speak English with others, they suffer from many challenges and force them to avoid speaking English. The first item asked the learners about the sufficiency of vocabulary, as shown below.

Table 5. Sufficiency of vocabulary

\begin{tabular}{lcc}
\hline First item: & I have no sufficient vocabulary & Responses \\
\hline Status & Frequency & $\%$ \\
\hline Strongly agree & 20 & 33 \\
\hline Agree & 30 & 50 \\
\hline No opinion & 1 & 1.7 \\
\hline Disagree & 5 & 8.3 \\
\hline Strongly disagree & 4 & 7 \\
\hline Total & 60 & 100 \\
\hline
\end{tabular}

With this item, we asked the learners about their sufficiency of vocabulary in English. Twenty of the learners, $33 \%$, answered strongly agree. In comparison, thirty of the learners, 50\%, replied simply agree.

Only one of the learners, $1.7 \%$, did not reply. Five of the learners, $8.3 \% 0$, responded disagree, while four of the learners, $7 \%$, answered strongly agree. This indicated that most learners had no sufficient vocabulary in English to help them use it in English-speaking skills.

In the following item, the researchers asked the learners about their ability to recall grammatical rules. 
Arab World English Journal (AWEJ) Volume 12. Number 1. March 2021

Challenges and Strategies in Teaching Speaking Skills to the Yemeni

Al-Hassaani \& Qaid

Table 6. Recalling of grammatical rules

Second item: I cannot recall grammatical rules

\begin{tabular}{lcc}
\hline Responses & & \\
\hline \multicolumn{1}{c}{ Status } & Frequency & $\%$ \\
\hline Strongly agree & 28 & 47 \\
\hline Agree & 16 & 26.7 \\
\hline No opinion & 2 & 3.3 \\
\hline Disagree & 8 & 13 \\
\hline Strongly disagree & 6 & 10 \\
\hline Total & 60 & 100
\end{tabular}

The researchers asked the learners whether they can recall the grammatical rules or not. Twenty-eight of the learners, $47 \%$, strongly agreed that they could not remember grammatical rules. Also, sixteen of the learners, $26.7 \%$, agreed that they could not remember the grammatical rules. Two of the learners, $3.3 \%$, did not respond. At the same time, eight of the learners, $13 \%$, disagreed that they could not remember the grammatical rules and six of the learners, $10 \%$, strongly disagreed that they could not remember the grammatical rules.

In the third item, the researchers asked the learners if they felt difficulty in speaking English on the phone.

Table 7. Feeling Difficulty to Speak English on the Phone

The third item: I feel it is difficult to speak English on the phone

\begin{tabular}{lcc}
\hline \multicolumn{2}{c}{ Responses } \\
\hline Status & Frequency & Percentage \\
\hline a. Strongly agree & 27 & 45 \\
b. Agree & 13 & 21.7 \\
c. Neutral & 6 & 10 \\
d. Disagree & 8 & 13.3 \\
e. Strongly disagree & 6 & 10 \\
$\quad$ Total & 60 & 100 \\
\hline
\end{tabular}

In this item, the researchers asked learners if they felt difficulty when they speak English on the phone; twenty-seven of the learners, $45 \%$, strongly decided that they felt a problem in speaking English on the phone, while thirteen of the learners, $21 \%$, just decided that they faced problem to speak English on the phone. Six of the learners, $10 \%$, opted for a neutral response. Eight of the learners, $13.3 \%$, disagreed that they faced problems to speak English on the phone. Six of the learners, $10 \%$, strongly decided that they faced problems to speak English on the phone. This indicated that only some of the learners could speak English on the phone, while most of the learners felt it was a problem to speak English on the phone. This was because of their poor background knowledge in English and insufficient practice to speak English and communicate with others. 
Arab World English Journal (AWEJ) Volume 12. Number 1. March 2021

Table 8. The Shyness of Learners to Speak English with Others

The fourth item: I feel shy to speak English with others

\begin{tabular}{lcc}
\hline & \multicolumn{2}{c}{ Responses } \\
\hline Status & Frequency & Percentage \\
\hline a. Strongly agree & 20 & 33.3 \\
b. Agree & 25 & 41.7 \\
c. Neutral & 3 & 5 \\
d. Disagree & 5 & 8.3 \\
e. Strongly disagree & 7 & 11.7 \\
\multicolumn{1}{c}{ Total } & 60 & 100
\end{tabular}

In this item, most learners agreed that they felt scared to speak English with others; twenty of the learners, 33.3\%, strongly decided that they felt scared to speak English with others. Twentyfive of the learners, $41.7 \%$, decided that they felt scared to speak English, while three of the learners, $5 \%$, opted for a neutral. Five of the learners, $8.3 \%$, decided for the same thing, and seven of them, 11.7\%, strongly disagreed that they felt shy to speak English with others. Most of the learners felt shy to communicate in English with others, which referred back to their lack of motivation and practice.

The other item asked the learners if they usually think in Arabic, then try to get the exact English match. The following table shows the responses of the learners.

Table 9. Learners' Thinking in Arabic Before Trying to Get an English Match

The fifth item: I usually think in Arabic, then I try to get the English match

\begin{tabular}{lcc}
\hline & \multicolumn{2}{c}{ Responses } \\
\hline Status & Frequency & Percentage \\
\hline a. Strongly Agree & 28 & 46.7 \\
b. Agree & 20 & 33.3 \\
c. Neutral & 2 & 3.3 \\
d. Disagree & 7 & 11.7 \\
e. Strongly Disagree & 3 & 5 \\
\multicolumn{1}{c}{ Total } & 60 & 100
\end{tabular}

The learners felt strongly that they typically think in Arabic, then they try to get the exact English match. Twenty-eight of the learners, $46.7 \%$, strongly decided that they typically think in Arabic, then they try to get the exact English match. Twenty of the learners, 33.3\%, decided on this item. Only two of the learners were neutral, $3.3 \%$, to this point. Seven of the learners, $11.7 \%$, disagreed that they think in Arabic and try to get the exact English match. Three of the learners, 5\%, opted strongly disagree for this item. This indicated that most of the learners usually think in Arabic to speak a specific sentence, then they try to get the exact English match words for it. This revealed that the learners had no enough experience in English-speaking skills. The following part discussed the reasons behind the problems of the learners in English-speaking skills. 
Arab World English Journal (AWEJ) Volume 12. Number 1. March 2021

Challenges and Strategies in Teaching Speaking Skills to the Yemeni

Al-Hassaani \& Qaid

Table 10. The significance of the Language Skills

The sixth item: How necessary the following skills for you when you study English?

\begin{tabular}{|c|c|c|c|c|c|c|c|c|c|c|c|c|}
\hline \multicolumn{13}{|c|}{ Responses } \\
\hline \multirow[t]{2}{*}{$\begin{array}{l}\text { Skill } \\
\text { Evaluation }\end{array}$} & \multicolumn{2}{|c|}{$\begin{array}{l}\text { Very } \\
\text { Important } \\
\end{array}$} & \multicolumn{2}{|c|}{ Important } & \multicolumn{2}{|c|}{ Neutral } & \multicolumn{2}{|c|}{$\begin{array}{l}\text { Less } \\
\text { Important }\end{array}$} & \multicolumn{2}{|c|}{$\begin{array}{l}\text { Not } \\
\text { Important }\end{array}$} & \multicolumn{2}{|l|}{ Total } \\
\hline & Freq. & $\%$ & Freq. & $\%$ & Freq. & $\%$ & Freq. & $\%$ & Freq. & $\%$ & Freq. & $\%$ \\
\hline Listening & 10 & 16.7 & 25 & 41.7 & 3 & 5 & 15 & 25 & 7 & 11.6 & 60 & 100 \\
\hline Speaking & 15 & 25 & 15 & 25 & 0 & 0 & 25 & 41.7 & 5 & 8.3 & 60 & 100 \\
\hline & 14 & 23.3 & 16 & 26.7 & 5 & 8.3 & 15 & 25 & 10 & 16.7 & 60 & 100 \\
\hline Reading & 15 & 25 & 20 & 33.3 & 0 & 0 & 17 & 28.3 & 8 & 13.4 & 60 & 100 \\
\hline Writing & & & & & & & & & & & & \\
\hline
\end{tabular}

The researchers asked the learners how necessary the four skills of the language Listening, Speaking, Reading and Writing. Regarding listening skill, only ten of the learners, 16.7\%, opted for very necessary; while twenty-five of the learners, $41.7 \%$, replied importantly; three of the learners, 5\%, not answered. In comparison, fifteen of the learners, $25 \%$, answered that listening is less essential, and seven of the learners, 11.6\%, opted for not important. Concerning speaking skills fifteen of the learners, $25 \%$, opted essential and fifteen of them, 25\%, said important; while twenty-five of the learners, $41.7 \%$, said that speaking is less important and five of them $8.3 \%$ opted not important. In reading skill fourteen of the learners, $23.3 \%$, said it is very significant and sixteen of them, $26.7 \%$, said important and five of the learners, $8.3 \%$, did not reply and fifteen of them, 25\%; while ten of the learners, $16.7 \%$, responded not important. About writing skill only fifteen of the learners, $25 \%$, said it is very important and twenty of them, $33.3 \%$, said important; while seventeen of them, $28.3 \%$, opted less important and only 8 of the learners, $13.4 \%$, replied not significant. This indicated that most of the learners had no recognition of the significance of the four language skills, which was clear from their answers above.

Table 11. Attending any English Classes in a Private Institute

Did you attend any English classes in a private institute?

\begin{tabular}{llcc}
\hline & \multicolumn{3}{c}{ Responses } \\
\hline Status & Yes & Frequency & Percentage \\
\hline b. No & 15 & 25 \\
\hline c. No response & 40 & 66.7 \\
\hline Total & 5 & 8.3 \\
\hline
\end{tabular}

The researchers asked the learners if they attended English classes in a private institute. Only fifteen of the learners, 25\%, said they attended English classes in a private institute. In comparison, forty of the respondents, $66.7 \%$, said not attended any English classes in a private institute and five of the respondents, $8.3 \%$, not answered. This indicated that most of the learners not participated in any English classes in a private institute. They could not afford the costs in private institutes and this reflected their actual performance in English-speaking skills. 
Arab World English Journal (AWEJ) Volume 12. Number 1. March 2021

Challenges and Strategies in Teaching Speaking Skills to the Yemeni

Al-Hassaani \& Qaid

Table 12. Primary Focus of English Teacher at High School Level What was the primary focus of your English teacher at the secondary school?

\section{Responses}

\begin{tabular}{lcc}
\hline \multicolumn{1}{c}{ Status } & Frequency & $\%$ \\
\hline a. & To make you memorize vocabulary and grammatical rules. & 80 \\
\hline b. $\begin{array}{l}\text { To make you use English for speaking according to the } \\
\text { context. }\end{array}$ & 8 & 13.4 \\
\hline c. No response & 2 & 3.3 \\
\hline Total & 60 & 100
\end{tabular}

The researchers asked the learners what their English teachers' primary focus at the secondary school level was. Fifty of the learners, $83.3 \%$, said that the primary focus of their English teachers was to make them memorize vocabulary and grammatical rules, while eight of the learners, 13.4\%, said that the primary focus of their English teachers was to make them use English for speaking according to the context. Only two of the learners had no answer. This indicated that only the minority of the learners said that they used English for speaking according to the context and the majority of the learners said that they used English only for memorizing words and rules of grammar.

Table 13. Evaluating speaking English of the Learners when they Entered to Aden University How can you evaluate your speaking English when you entered to Aden University?

\begin{tabular}{cccc} 
& \multicolumn{3}{c}{ Responses } \\
\hline Status & Frequency & Percentage \\
\hline a. Very good & 9 & 15 \\
\hline b. & Good & 6 & 10 \\
\hline c. Average & 10 & 16.7 \\
\hline d. & Poor & 20 & 33.3 \\
\hline e. Very poor & 15 & 25 \\
\hline Total & 60 & 100 \\
\hline
\end{tabular}

In this item, the researchers asked the learners to evaluate their speaking English when they entered Aden University; only nine of the learners, 15\%, said they were perfect and six of the learners, $10 \%$, said they were right, ten of the learners, $16.7 \%$, replied with average. In comparison, twenty of the learners, 33.3\%, said they were poor and fifteen of the learners, $25 \%$, said they were very poor in speaking English when they entered university. This implied that most of the learners were poor and very poor in speaking English when entering Aden University. 
Arab World English Journal (AWEJ) Volume 12. Number 1. March 2021

Challenges and Strategies in Teaching Speaking Skills to the Yemeni

Al-Hassaani \& Qaid

Table 14. Choosing the Learners English as their Major of Study

Why did you choose English as your major of study?

\section{Responses}

a. I want to speak English, and I like it very much.

Frequency Percentage

b. I just want to get a degree in order to get a job.

$11 \quad 18.3$

$40 \quad 66.7$

c. English is essential to me because I like to have a good relation with people who speak English.

Total

60

100

In this connection, the researchers asked the learners why they chose English as their major. Eleven of the learners, $18.3 \%$, said they want to speak English and they liked it very much, while forty of them, $66.7 \%$, said they just want to get a degree to get a job. Nine of the learners, $15 \%$, said English is vital because they like to have good relations with people who speak English. This statistical figure shows that the majority of the students just want to get a degree to get a job; besides, there was not right motivation towards learning the English language itself from the side of English teachers.

The other item asked if the learners think that good English knowledge gives them room for the world and modern technology

Table 15. Good English Knowledge

I think good English knowledge gives room to the world and modern technology.

Responses

\begin{tabular}{llll}
\hline & Status & Frequency & Percentage \\
\hline a. & Strongly agree & 20 & 33.3 \\
\hline b. & Agree & 20 & 33.3 \\
\hline c. & Neutral & 2 & 3.3 \\
\hline d. & Disagree & 10 & 16.7 \\
\hline e. & Strongly disagree & 8 & 13.4 \\
\hline & Total & 60 & 100
\end{tabular}

In this item, the researchers asked the learners if they think a good understanding of English gives room to the world and modern technology; twenty of the learners, $33.3 \%$, strongly agreed that a good understanding of English gives room to the world and modern technology. Twenty of the learners, $33.3 \%$, agreed on this point and two of the students, 3.3\%, were neutral. Ten of the learners, $16.7 \%$, disagreed that a good English knowledge gives room to the world and modern technology. In comparison, only eight of the learners, $13.4 \%$, strongly disagreed on this point. This statistical figure revealed that most of the learners understood the importance of learning English to enable them to communicate with the outside world. 
The fourth part of the questionnaire dealt with exposure of the learners to English, and their opinions about the effectiveness of the syllabus and teaching materials of English-speaking course at Aden University.

In the first item of this part, the researchers asked the learners how often they speak English. Table 16. Speaking English in the classroom How often do you speak English in the classroom?

\begin{tabular}{llcc}
\hline \multicolumn{4}{c}{ Responses } \\
\hline \multicolumn{2}{c}{ Status } & Frequency & Percentage \\
\hline a. & Very often & 5 & 8.3 \\
\hline b. & Often & 5 & 8.3 \\
\hline c. & Sometimes & 28 & 46.7 \\
\hline d. & Rarely & 20 & 33.3 \\
\hline e. & Never & 2 & 3.4 \\
\hline & Total & 60 & 100
\end{tabular}

In this item, the researchers asked the learners about how often they speak English in the classroom. Five of the learners, $8.3 \%$, replied they very often speak English in the classroom and five of them, $8.3 \%$, answered they often talk English in the class, while twenty-eight of the learners, 46.7\%, replied they sometimes speak English in the classroom and twenty of them, $33.3 \%$, said they rarely talk English. Only two of the learners, 3.4\%, responded they never speak English in the class. This implied that most of the learners had no enough practice in Englishspeaking skills.

Table 17. Watching English Movies and News Channels How often do you watch English Movies, News Channels, or Reading Newspapers?

\begin{tabular}{llll}
\hline & & \multicolumn{2}{c}{ Responses } \\
\hline & Status & Frequency & Percentage \\
\hline a. & Very often & 2 & 3.3 \\
\hline b. & Often & 3 & 5 \\
\hline c. & Sometimes & 10 & 16.7 \\
\hline d. & Rarely & 15 & 25 \\
\hline e. & Never & 30 & 50 \\
\hline & Total & 60 & 100
\end{tabular}

The researchers asked the learners to respond whether they watch English movies, news channels, or reading newspapers. Only two of the learners, $3.3 \%$, said they very often do those things, and three of them, $5 \%$, said they usually follow that; ten of the learners, $16.7 \%$, replied they sometimes do it, fifteen of the learners, $25 \%$, said they rarely watch and read those things mentioned above. Thirty of the learners, 50\%, responded that they never watch English movies, news channels, or reading English newspapers. The statistical data revealed that most of the learners were not interested in watching or reading English items. This indicated that there were 
no motives to push the Yemeni learners towards learning English through displaying at least simple English movies or even simple conversations on the screen.

Table 18. Methods Employed by the Teachers

Are your English-speaking skills classes student-centered or teacher-centered?

\begin{tabular}{cccc} 
& \multicolumn{3}{c}{ Responses } \\
\hline Status & Frequency & Percentage \\
\hline a. a student-centered & 10 & 16.67 \\
\hline b. a teacher-centered & 50 & 83.33 \\
\hline Total & 60 & 100 \\
\hline
\end{tabular}

In this item, the researchers asked the learners if the method of teaching in the classroom was student-centered or teacher-centered; ten of the learners, $16.67 \%$, said it was student-centered, and fifty of the learners, 83.33\%, responded that the method of teaching English classes in the classroom was teacher-centered. This indicated no effective participation at the side of the learners in learning English-speaking classes, and the teacher role only was dominated in the classroom.

The final section of the questionnaire was about the learners' opinion in: -1) The appropriateness and sufficiency of the current syllabus, as in table 19. 2) The appropriateness and sufficiency of the current teaching materials, as in table 20.3) The sufficiency of time allotted for teaching English-speaking skills, as in table 21.

Table 19. Appropriateness and Sufficiency of the Current Syllabus Topics

I think the current Syllabus topics of speaking are not appropriate and sufficient.

\begin{tabular}{|c|c|c|}
\hline \multicolumn{3}{|c|}{ Responses } \\
\hline Status & Frequency & Percentage \\
\hline a. Strongly agree & 30 & 50 \\
\hline b. Agree & 20 & 33.3 \\
\hline c. Neutral & 3 & 5 \\
\hline d. Disagree & 5 & 8.3 \\
\hline e. Strongly disagree & 2 & 3.4 \\
\hline Total & 60 & 100 \\
\hline
\end{tabular}

When the researchers asked the learners if they thought the English-speaking skills course's current syllabus topics were not appropriate and sufficient, thirty of the learners, 50\%, strongly decided that the current syllabus issues were not appropriate and sufficient. Twenty of the learners, $33.3 \%$, decided about that. Three of the learners, 5\%, were neutral and not answered. In comparison, five of the learners, $8.3 \%$, disagreed about this point, and two of the learners, 3.4\%, strongly disagreed that the current syllabus issues were not appropriate and enough for the learners at Aden University. Therefore, these responses revealed that the current syllabus topics need to be developed and changed by a new to match the learners' needs at Aden University. 
Arab World English Journal (AWEJ) Volume 12. Number 1. March 2021

Table 20. Appropriateness and Sufficiency of the Current Teaching Materials

I think the current teaching materials of English-speaking skills are not appropriate and sufficient.

\section{Responses}

\begin{tabular}{llll}
\hline \multicolumn{2}{l}{ Status } & Frequency & Percentage \\
\hline a. & Strongly agree & 24 & 40 \\
\hline b. & Agree & 26 & 43.4 \\
\hline c. & Neutral & 2 & 3.3 \\
\hline d. & Disagree & 5 & 8.3 \\
\hline e. & Strongly disagree & 3 & 5 \\
\hline & Total & 60 & 100
\end{tabular}

The researchers asked the learners to respond if they thought that the English-speaking skills course's current teaching materials are not appropriate and sufficient. Twenty-four of the learners, $40 \%$, strongly agreed that the teaching materials are not appropriate and sufficient and twenty-six of the learners, $43.4 \%$, said the same thing, while two of the learners, $3.3 \%$, had no response, and only five of the learners, $8.3 \%$, disagreed that the teaching materials are not appropriate and sufficient and three of the learners, 5\%, strongly disagreed for the same thing. This indicated that there are shortages of teaching materials and are not adequate to prepare the learners for English-speaking skills. Therefore, supplementary materials are needed for the learners to learn how to communicate in English with others. Generally speaking, an appropriate communicative language teaching syllabus and relevant materials go a long way in making the learning of English-speaking skills useful, constructive, and practical.

Table 21. Sufficiency of Time Allotted for Teaching English Speaking Skills I think the time allotted is not sufficient to give the learners a chance to speak English in class.

\section{Responses}

\begin{tabular}{llll}
\hline \multicolumn{2}{l}{ Status } & Frequency & Percentage \\
\hline a. & Strongly agree & 27 & 45 \\
\hline b. & Agree & 26 & 43.4 \\
\hline c. & Neutral & 2 & 3.3 \\
\hline d. & Disagree & 3 & 5 \\
\hline e. & Strongly disagree & 2 & 3.3 \\
& & \\
\hline & Total & 60 & 100
\end{tabular}

In the final item, the researchers asked the learners if they thought that the time allotted was insufficient to give them a chance to speak English in the classroom. Twenty-seven of the 
learners, $45 \%$, strongly agreed that the time allotted was not enough to give the learners a chance to speak English in class, and twenty-six of the learners, 43.4\%, approved for the same thing, while two of the learners, $3.3 \%$, were neutral. Three of the learners, $5 \%$, disagreed and two of them, $3.3 \%$, strongly disagreed for the same thing. Therefore, these responses revealed that the learners had no enough time to practice English-speaking skills in the classroom. I

\section{Findings of the Study}

The findings of this study revealed that the English classes were teacher-centered rather than student-centered. There was a clear teacher dominance in English-speaking skills classes. The current study revealed that the Yemeni EFL learners suffered from not getting enough time to practice in different real-life situations. The learners can hardly observe the motivation of the teachers. The existing methods of teaching English-speaking skills at Aden University were not practical and needed a change. The majority of the learners felt that if they tried to speak, they might make mistakes and the other students laughed at them in the classroom. Teachers of English-speaking skills must adhere to new methods and techniques in teaching Englishspeaking skills at Aden University. The current teaching materials and the syllabus of the English-speaking skills are not appropriate and effective.

\section{Recommendations}

Teachers of English-speaking skills at Aden University should use the appropriate tasks and activities to improve the learners' level. Besides, the Yemeni EFL learners should have the desire to learn English at the early stages. Learning English at early stages in Yemen would directly enhance Yemeni EFL learners' improvement in English-speaking skills. Teachers of Englishspeaking skills at Aden university should provide second-year learners with various real-life situations in learning and accurate materials for teaching English-speaking skills.

There is a necessity for using a communicative syllabus and communicative materials for teaching English-speaking skills at Aden University. The Yemeni EFL learners should have more time to practice the English-speaking skills to improve their proficiency and fluency. Some of the teachers ignore the learners' involvement in authentic and real situations and oral communication activities during the language learning classes in speaking lessons. Teachers at Aden University should provide the learners with real-life situations and accurate materials in teaching English-speaking skills to improve their level.

Yemeni learners of English Department at Aden university should know to master the essential elements of English-speaking skills. English teachers at Aden University should create a good environment for interaction to improve Yemeni EFL learners' level in English-speaking skills. Teaching strategies in teaching English-speaking skills should use a student-centered approach instead of a teacher-centered one. Communicative teaching materials and communicative syllabus topics should replace the current syllabus and teaching materials for teaching English-speaking skills at Aden University. WhatsApp was found as a useful tool to motivate students and reduce their anxiety during speaking English (Ali \& Ben-Hadi; 2019). Therefore, technology should be used to motivate EFL students at Aden University to speak English with no or less anxiety. 
Arab World English Journal (AWEJ) Volume 12. Number 1. March 2021

Al-Hassaani \& Qaid

\section{Conclusion}

In conclusion, we can say that the Yemeni EFL learners need help to overcome their Englishspeaking skills challenges. Thus, using a communicative language teaching approach in teaching and learning English-speaking skills would benefit both the teachers and the learners. Teachers should play a significant role in teaching the Yemeni EFL learners the strategies of Englishspeaking skills. The teachers at Aden University should also help the learners to improve their English-speaking skills and overcome their challenges when speaking in English. The syllabus and teaching materials need a change in College of Education, Saber, Aden University. If the reforms are meticulously implemented, there is absolutely no doubt that teachers will find meaning, significance, and relevance in teaching and learning the English-speaking skills at Aden University.

\section{About the Authors}

Dr. Abdulbari Mahboob Ahmed Al-Hassaani is a Ph.D. holder. He graduated from India, in 2009. He is an assistant professor of applied linguistics, English Department, Aden University. $\mathrm{He}$ is currently teaching in English Department, College of Arts, University of Bisha, Saudi Arabia. He taught many courses in English Department https://orcid.org/0000-0002-0017-4436.

Dr. Abdukarim Fadhl Mahmood Al-salmi is a Ph.D. holder, graduated from India, in 2008. He is an assistant professor in methods of teaching, English Department, Aden University. He is currently working at Aden University. He is also an assistant dean for the academic affairs, Community college in Yemen https://orcid.org/0000-0003-4204-7176.

\section{References}

Al-Ahdal, A. A. M. H., Alfallaj, F., Al-Awaied, S., \& Al-Hattami, A. A. (2014). A comparative study of proficiency in speaking and writing among EFL learners in Saudi Arabia. American International Journal of Contemporary Research, 4(2), 141149.http//aijcrnet.com/journal/Vol_4_No_2_February_2014/19.pdf

Al-Ghazali, S., \& Qaid, A. M. (2019). Speech and Articulation Rates of Speaking Fluency by Yemeni EFL Learners. Language in India, 19(2).

Al Hosni, S. (2014). Speaking Difficulties Encountered by Young EFL Learners. International Journal on Studies in English Language and Literature (IJSELL) 2 (6), 2-30.

Ali, J. K. M., Shamsan, M.A., Guduru, R., \& Yemmela, N. (2019) Attitudes of Saudi EFL Learners towards Speaking Skills. Arab World English Journal, 10 (2) 253-364.

Ali, J.K.M., \& Bin-Hady, W. R. A. (2019). A Study of EFL Students' Attitudes, Motivation and Anxiety towards WhatsApp as a Language Learning Tool. Arab World English Journal (AWEJ) Special Issue on CALL (5). 289-298 DOI: https://dx.doi.org/10.24093/awej/call5.19

Al-Tamimi, N. O. M. (2014). Public speaking instruction: abridge to improve English speaking competence and reducing communication apprehension. International journal of linguistics and communication, 2(4), 45-68.

Brown, H.D (2007). Principles of Language Learning and Teaching. White Plains, NY: Pearson Longman. 
Arab World English Journal (AWEJ) Volume 12. Number 1. March 2021

Dewi, A. (2015). Perception of English: A study of staff and students at universities in Yogyakarta, Indonesia. Cambridge, UK: Cambridge Scholars Publishing.

Gathumbi, A. \& Masembi, S.C. (2005). Principles and Techniques in Language Teaching. Nairobi: Jomo Kenyatta Foundation.

Richard, J.C. (2006). Communicative Language Teaching Today. New York: Cambridge University Press.

Richards, J.C., \& Rodgers, T.S. (1986). Approaches and Methods in Language Teaching. Cambridge: Cambridge University Press.

Sarantakos, S. (1998). Social Research. Hong Kong: Macmillan Press Ltd.

Shaw, P.A. (1982). Ad hoc needs analysis. Modern English Teacher, 9(1), 12-14. 